\title{
Hubert Michalak
}

Uniwersytet Opolski

\section{TRANSMISJE PAMIECCI}

\section{PRZED WEJŚCIEM NA SCENĘ}

Jedno z ostatnich przedstawień wyreżyserowanych przez Jana Dormana, realizacja sztuki Hanny Krall Powiedz, że jestem... w Teatrze Dramatycznym im. Jerzego Szaniawskiego w Wałbrzychu ${ }^{1}$ (prem. 16 VI 1985), było wyjątkowe przynajmniej z dwóch powodów. Po pierwsze, po przymusowym odejściu na emeryturę i opuszczeniu Teatru Dzieci Zagłębia w Będzinie twórca współpracował przede wszystkim z teatrami lalkowymi lub scenami dla młodych widzów, zaś TDSz był teatrem dramatycznym i grał głównie dla dorosłych. Wcześniej Dorman zaledwie dwa razy reżyserował w tego typu instytucji: w $1983 \mathrm{w}$ Teatrze Małym w Tychach przygotował Niebieskiego ptaka Maurice'a Maeterlincka, a w 1984 Dziecko i czary Maurice'a Ravela w Operze Śląskiej w Bytomiu. Drugim powodem wyróżniającym wałbrzyską realizację było pełne pietyzmu podejście do tekstu Krall. I to na wielu poziomach: od poszczególnych kwestii do ogólnej struktury. „Transponując utwór na scenę, przede wszystkim poddaję go demontażowi, aby z kolei montować nowy szkielet, na którym będę mógł zawieszać wszystkie elementy potrzebne do działania scenicznego" ${ }^{2}$ - deklarował reżyser pod koniec lat sześćdziesiątych. Tym razem jednak nie zdekonstruował struktury dramaturgicznej. Stworzył spektakl wiernie podążający za treścią dramatu, co mogło być zaskakujące szczególnie dla widzów znających jego wcześniejsze prace.

Sztuka Powiedz, że jestem..., poruszająca problematykę Zagłady widzianej oczyma dziecka, została wyróżniona III nagrodą w konkursie dramatopisarskim ogłoszonym przez TDSz, a związanym z organizowanym co dwa lata przez tę

Dalej: TDSz.

J. Dorman, Moje credo artystyczne, [w:] Świadomość teatru. Polska myśl teatralna drugiej połowy XX wieku, red. W. Dudzik, Warszawa 2007, s. 42-43. Pierwodruk: „Polska” 1969 nr 6. 
placówkę Ogólnopolskim Festiwalem Sztuk Dziecięcych i Młodzieżowych ${ }^{3}$ (inscenizacja Dormana uświetniła IV edycję Festiwalu ${ }^{4}$ ). Zaproszenie do realizacji tego właśnie tytułu skierował do Dormana Waldemar Stasicki, dyrektor i kierownik artystyczny TDSz w latach 1982-1989. Jako dyrektor preferował on ,teatr współczesny w niezbyt awangardowym wydaniu"s, Dormana zaś zaprosił do realizacji, znając go jako specjalistę od teatru dla młodego widza i człowieka oddanego sprawie - „dyr. Stasicki wie o tym doskonale, że moje zainteresowanie teatrem dla dzieci i młodzieży to sprawa całego mojego życia"

Tematyka wojenna pojawiała się w Dormanowskiej twórczości od wielu lat. Warto przywołać w tym kontekście jego współpracę z Państwowym Teatrem Lalek w Wałbrzychu, gdzie w 1980 przygotował premierę, a w 1984 wznowienie (z częściowo zmienioną obsadą) przedstawienia Która godzina, również związanego tematycznie z II wojną światową. Myślenie reżysera o wojennej problematyce ewoluowało od podejścia uogólniającego do akcentów emocjonalnych. Podsumowała je Krystyna Mazur, porównując występ wałbrzyskich lalkarzy z wcześniejszą, będzińską realizacją Której godziny: ,przedstawienie [...] rezonowało nie pacyfistyczną nutą, jak w latach sześćdziesiątych, ale zajęło nas i rozbawiło wzruszająco solidarnym strajkiem zegarów". Powiedz, że jestem..., uznane za najciekawsze wydarzenie wszystkich sezonów dyrekcji Stasickiego ${ }^{8}$, było, jak się wydaje, kolejnym ogniwem w ewolucji myśli Dormanowskiej dotyczącej artystycznego przepracowania traumatycznego doświadczenia II wojny światowej.

Należy podkreślić, iż Powiedz, że jestem ... było jednym z pierwszych w Polsce przedstawień dla młodego widza wprost podejmujących temat Zagłady. ${ }^{9}$

3 Imprezę powołano do istnienia w Międzynarodowym Roku Dziecka, pierwsza edycja miała miejsce w 1979 pod protektoratem Ministerstwa Kultury i Sztuki, Ministerstwa Oświaty i Wychowania, Urzędu Wojewódzkiego w Wałbrzychu, Głównej Kwatery Związku Harcerstwa Polskiego i Zarządu Głównego Towarzystwa Przyjaciół Dzieci. Ze strony TDSz głównym inicjatorem był Andrzej Maria Marczewski. Festiwal miał swoje mocniejsze i słabsze edycje, wypełniał jednak istotną niszę w ówczesnej polskiej kulturze teatralnej, promując polskie dramaty i przedstawienia dla młodego widza. Jeszcze podczas dyrekcji Stasickiego zaprzestano organizacji festiwalu, którego piąta i ostatnia edycja odbyła się w 1987.

4 Festiwal trwał od 17 do 23 VI 1985, pokaz festiwalowy omawianego przedstawienia odbył się na Scenie Studyjnej 21 VI 1985 o 17:00. Zob. afisz festiwalu, czerwiec 1985, sklejka „Powiedz, że jestem...", Archiwum Jana Dormana w Instytucie Teatralnym im. Zbigniewa Raszewskiego w Warszawie (dalej: AJD/IT).

5 K. Migdałowska, Dyrekcje z importu, [w:] 50 (stownie: pięćdziesiat). Teatr Dramatyczny im. Jerzego Szaniawskiego w Wałbrzychu (1964-2014), Wałbrzych 2014, s. 83.

6 J. Dorman, kwiecień 1985, rkps, sklejka „Powiedz, że jestem...”, op. cit.

7 Idem, Watbrzych, czyli mój wyznawca - Kobrzyński, [w:] Która godzina [program], Będzin 1964, e-teatr.pl/pl/programy/2013 12/55024/ktora_godzina teatr_lalek_walbrzych_ 1984.

8 K. Migdałowska, op. cit.

9 Osobnym zagadnieniem jest obecność na polskich scenach Pamiętnika Anny Frank Frances Goodrich i Alberta Hacketta, który doczekał się w latach 1957-1961 ośmiu realizacji scenicznych i jednej radiowej. Fenomen tego tytułu i jego miejsce w teatralnej recepcji Zagłady w Polsce omawia Grzegorz Niziołek, Polski teatr Zagłady, Warszawa 2013, s. 221-241. 
W tamtym okresie polski teatr dopiero uczył się strategii scenicznych i języka rozmowy o doświadczeniu Holokaustu. Przez cztery powojenne dekady spektakle nawiązujące do Zagłady wprost wypierano poza główny nurt, sam Holokaust zaś był tematem tabu. Jeśli pojawiał się na scenach, był maskowany, świadomie bądź nieświadomie ukrywany $\mathrm{w}$ głębokiej strukturze przedstawienia. ${ }^{10}$ $\mathrm{Na}$ kilka lat przed zmianą ustrojową społeczeństwo wydawało się jednak już przygotowane do scenicznej rozmowy o Holokauście: w dorosłość wchodziło kolejne pokolenie, które wojnę poznało w zapośredniczonym przekazie, zwiększył się również dystans czasowy od tragicznych wydarzeń. „Mamy nadzieję, że nasza propozycja - trudna sztuka w niekonwencjonalnej inscenizacji - będzie właściwym krokiem w stronę teatru dla młodzieży"11 - takim sformułowaniem zakończono tekst programu towarzyszącego wałbrzyskiej produkcji. Zgadywać można, że stwierdzenie to miało jednocześnie przygotować widzów na problematykę i zagadnienia realizacyjne spektaklu, jak i być swoistą asekuracją ze strony TDSz.

Sztuka Krall nawiązuje do heroicznego ratowania Żydów podczas Zagłady i jego konsekwencji. Samo słowo „Żyd” nie pojawia się w tekście, nie ma jednak wątpliwości, o kim traktuje opowieść. Reżyser zresztą akcentami inscenizacyjnymi dopełnił przemilczenia tekstu: „Krall nie mówi do końca - więc muszę powiedzieć ja - bo kto?"12 - zanotował. Z kolei podczas prób tematyka Zagłady nie była wiodącym tematem rozmów twórców. Stawała się raczej punktem wyjścia do bardziej ogólnych spostrzeżeń:

rozmawialiśmy o Polakach, Żydach i ich wzajemnych stosunkach [...]. Dorman podkreślał, że to nigdy nie były łatwe relacje. Zresztą nie mówiliśmy tylko o kwestii polsko-żydowskiej, ale w ogóle międzyludzkiej, On podnosił to ponad relację Polak - Żyd. ${ }^{13}$

Autorka uczyniła Zagładę motorem akcji dramatycznej w sposób paradoksalny: usunęła ją ze sceny. Podążając za tą koncepcją, inscenizator zapewnił widzom komfort oglądania bez podglądania: dzięki temu, że zbrodnia nie była fizycznie obecna, realizacja unikała stawiania widza w sytuacji bystandera. ${ }^{14}$ Równocześnie główna bohaterka, Dziewczynka I (Żydówka chowana za szafą), nakreślona z empatią i czułością, na sposób emblematyczny uosabiała tragedię narodu żydowskiego. Dzięki jednostkowemu potraktowaniu, opozycyjnemu wobec masowości

10 Ta uwaga ma na celu jedynie całościowe, z konieczności uogólniające, ujęcie przedstawień tzw. głównego nurtu. Na przebadanie pod tym kątem czeka wciąż repertuar teatrów innych niż dramatyczne.

11 b.a., Jaki teatr?, [w:] Powiedz, że jestem..., [program], Wałbrzych 1985, e-teatr.pl/p1/programy/2015 09/67808/powiedz ze jestem teatr dramatyczny walbrzych 1985.pdf.

12 J. Dorman, notatka bez daty, rkps, sklejka „Powiedz, że jestem...”, op. cit.

13 Wywiad z Jackiem Jackowiczem przeprowadzony przez Huberta Michalaka, 20 XII 2018, zapis, AJD/ IT.

${ }_{14} \mathrm{Tj}$. postronnego obserwatora Zagłady. Zob. uwagi na ten temat i omówienie określenia wprowadzonego przez Raula Hilberga, G. Niziołek, op. cit., zwłaszcza s. 31-37. 
zbrodni nazistowskiej, Dziewczynka I nie zyskiwała rysów unperson ${ }^{15}$, przeciwnie, urastała do rangi osoby, o której życie trzeba walczyć wbrew wszystkiemu, nawet wbrew samemu sobie.

Wspomniana już pokoleniowa gotowość zaważyła na wyróżnieniu tekstu Krall w wałbrzyskim konkursie dramatopisarskim. Za głosem generacyjnym podążył również reżyser. Choć przyznawał: „w zasadzie nie biorę na warsztat sztuk współczesnych autorów [...] wolę klasykę"16, po namowach ze strony Stasickiego podjął się tego zadania. Wcześniej zresztą obiecał dyrektorowi wystawić w TDSz ,jakąś sztukę dla dzieci”"17, być może więc w ten sposób wywiązywał się ze wstępnie podjętego zobowiązania. ${ }^{18}$

Skupienie na treściach tekstu było praktyką odmienną od dotychczasowych metod pracy Dormana. We wcześniejszych przedstawieniach swobodnym artystycznym gestem naruszał utwory pierwotne, używał ich do zbudowania nowych struktur dramaturgicznych, opartych na frazach, rymach, rytmicznych powtórzeniach. Waloryzując warstwę werbalną, obecną w jego spektaklach nieomal sensualnie, przenosił uwagę widzów z literacko rozumianych znaczeń na performatywne tu i teraz teatralnego zdarzenia: rytmika słów oraz intonacja i fraza daleka od typowego realizmu psychologicznego stawały się performatywnym, właściwym scenie, a nie literaturze, komunikatem. Zmiana strategii mogła być sygnałem przenikliwości i świadomości reżyserskiej oraz świadectwem wyczulenia na pokoleniową zmianę odbiorców. Rezonujący ze współczesnością Dorman daleki był już od pojmowania teatru jako przestrzeni przede wszystkim terapeutycznej, wspierającej proces wychodzenia $z$ traumy ${ }^{19}$, czyli koncepcji, która przez dekady towarzyszyła jego pracy. Wspólnie z widzami przepracował opowieść Krall, mówiąc o Zagładzie przez pryzmat pamięci pojmowanej na wiele sposobów. Rozumiał ją jako kolekcjonowanie osobistych wspomnień i wrażeń, pamięć zbiorową wyrażaną w wielkich narracjach, pamięć przedmiotu, wspólną wiedzę, mikronarracje. Na podstawie utworu Krall zbudował migotliwie przenikające się płaszczyzny, w których zetknął historię i współczesność, nadał szczególną rangę rekwizytom i rytmizowanym frazom tekstowym. Nie zapomniał również o swojej pamięci i pamięci o sobie, wprowadzając topikę charakterystyczną dla własnej twórczości.

15 Osoba, której życie przestaje być w danych okolicznościach warte ochrony. Zob. G. Niziołek, op. cit., s. 69.

16 J. Dorman, notatka, luty 1985, rkps, sklejka „Powiedz, że jestem...”, op. cit.

17 Idem, notatka, 15 II 1985, rkps, ibidem.

18 W innym miejscu Dorman notuje: „Koterla uważa, że winienem tę przyjemność dramatowi”, co poszerza przestrzeń domysłów na temat negocjacji, jakie mogły się odbyć między reżyserem a dyrektorem Stasickim. Eugeniusz Koterla był dyrektorem Państwowego Teatru Lalek w Wałbrzychu w latach 1981-2004. J. Dorman, notatka, 17 II 1985, rkps, ibidem.

19 Zob. np. E. Tomaszewska, Jan Dorman. Poeta teatru, Katowice 2010, zwłaszcza s. 88-108. 


\section{NA SCENIE}

\section{Postaci}

Dramat Krall zawiera się w kilku zaledwie scenach i toczy w dwóch planach czasowych. ${ }^{20} \mathrm{~W}$ planie historycznym, tj. podczas II wojny światowej, opowiada o dziewczynce ukrywającej się za szafą (Dziewczynka I, opisywana jako ciemnowłosa i ciemnooka - kolor jej oczu nazywany jest stygmatyzującym), w mieszkaniu, które należy do rodziny innej dziewczynki, nieco od niej starszej (Dziewczynka II, ,jasnowłosa, [...] pogodna, rozumna" $\left.{ }^{21}\right)$. Ramą opowieści jest współczesne spotkanie Dziewczynek, już jako dojrzałych kobiet - Pani I wraz z córką oraz Pani II - w tym samym mieszkaniu.

Krall podkreśliła w didaskaliach, że pewne role powinny być obsadzone przez tych samych wykonawców. Zdaniem autorki odpowiadające sobie postaci to: Dziewczynka I i Córka Pani I, Dziewczynka II i Pani II, Chłopiec I i Chłopiec II. Dorman zaingerował w tę sugestię. Rezygnując z bezpośredniego przeniesienia tożsamości dziecięcych bohaterek na dojrzałe kobiety, zdecydował, że Violetta Uryga grająca Dziewczynkę II (czyli Aryjkę) zagra Panią I (dorosłą Żydówkę), jakby sygnalizował, że stygmat nie jest na stałe przypisany do osoby.

Wałbrzyska obsada premierowa była następująca: Dziewczynka I i Córka Pani I - Katarzyna Skolik; Dziewczynka II, Pani I oraz Głos Pani - Violetta Uryga; Pani II i Matka Dziewczynki II - Teresa Musiałek; Chłopiec - Tadeusz Sokołowski; Mężczyzna - Jacek Jackowicz; Pani Stachowa - Krystyna Krasowska-Stożek; Chłopiec I i Chłopiec II - Tadeusz Sokołowski. ${ }^{22}$

Takie ustawienie ról zdaniem krytyki „,utrudniało odbiór sztuki osobom, które wcześniej nie czytały dramatu". ${ }^{23}$ Ponadto reżyser, ufając własnej konstrukcji myślowej, nie podparł transformacji Urygi środkami wizualnymi, co dodatkowo zaciemniło obraz relacji scenicznych.

\section{Transmitery pamięci}

Strona wizualna spektaklu od samego początku ewokowała atmosferę smutku, żałoby i odchodzenia: scenograf, Wacław Kula, ubrał postaci na czarno lub

20 Analiza opisowa przedstawienia oparta jest o notatki Dormana (J. Dorman, luty-czerwiec 1985, rkps/mps, sklejka „Powiedz, że jestem...”, op. cit.,) i opis Krzysztofa Grębskiego (K. Grębski, „Monografia spektaklu Hanny Krall Powiedz, że jestem... w reżyserii Jana Dormana zrealizowanego na Warsztatach Artystycznych w Świdwinie", praca magisterska pod kier. doc. dr. hab. Jerzego Jastrzębskiego, Państwowa Wyższa Szkoła Teatralna im. Ludwika Solskiego w Krakowie, Wydziały Zamiejscowe we Wrocławiu, Wydział Lalkarski, Wrocław 1987, mps, AJD/IT). Na potrzeby artykułu oba opisy zostają potraktowane jako równoważne, co znajdzie uzasadnienie dalej.

${ }_{21}$ H. Krall, Powiedz, że jestem..., mps, przed s. 1, sklejka „Powiedz, że jestem...”, op. cit.

22 Każdego z wykonawców Dorman wcześniej widział na scenie, ponadto z Krystyną Krasowską-Stożek pracował, a Violetta Uryga była jego studentką. Szerzej o procesie decyzyjnym: J. Dorman, Pisanie reżysera do młodych widzów, [w:] Powiedz, że jestem... [program], op. cit.

23 K. Kucharski, Powiedz, że jestem, „Gazeta Robotnicza” 1985 nr 29, wycinek z AJD/IT. 
w odcienie szarości, Scenę Studyjną zaś, na której grano spektakl, otaczała czerń ścian i podłogi (,czarną salą” nazywali ją wałbrzyscy aktorzy ${ }^{24}$ ). Dzięki jednolitej tonacji tym mocniejsze były akcenty kolorystyczne.

„Sala jest nietypowa. Nie ma [...] osobnej sceny, [...] klasycznej widowni. Widz siedzi bardzo blisko grających. Zdawałoby się, że uczestniczy w grze aktorów" 25 - notował Dorman. W głębi sceny znalazły się antropomorficzne, obwiązane bandażami, utrzymane $\mathrm{w}$ jednolitej kolorystyce manekiny o zatartych twarzach, mogące budzić skojarzenia z estetyką przedstawień Tadeusza Kantora. Po prawej stronie stanęło pianino, przy nim krzesła, w głębi - okazała szafa, dominujący element scenograficzny. Na proscenium czarny bujany fotel, nad sceną kandelabr. Na szafie znajdowało się wysokie czako ułańskie, element z innego porządku historycznego, zakłócający czasoprzestrzeń, ,po dziadku czy pradziadku [...] z okresu powstania listopadowego". ${ }^{26}$ Podążając za dramatopisarskim pomysłem na przestrzeń, Dorman na jednym z rysunków tak zaplanował układ sceny: w głębi „scena właściwa”, ,proscenium czyli czas teraźniejszy” i osobno zaznaczona „widownia”. W tej samej notatce zapisał m.in.: „Trzeba będzie zastosować obrotówkę a może kupić własną szafę"27 (ostatecznie plan zastosowania sceny obrotowej nie doszedł do skutku ${ }^{28}$ ).

Przedstawienie afirmowało pamięć zamkniętą w świadkach przeszłości, a były nimi dwie kobiety i szafa. Ta ostatnia, to coś więcej niż tylko mebel. Można zaryzykować stwierdzenie, że wzięła udział w spektaklu na prawach aktorki. Została kupiona, nie wykonana w pracowni ${ }^{29}$, co wnosiło do przedstawienia szczególną, pozateatralną realność obecności, prawdę przedmiotu wpisaną w jego kształt, pierwotne przeznaczenie i niefikcyjność. Stanowiąc punkt odniesienia, kotwicę dla pamięci, uruchamiała mapę skojarzeń. Jej nieme świadectwo jednocześnie wspomagało i zakłócało powrót do przeszłości: fizyczna obecność pozwalała w sposób zmysłowy powrócić do minionych lat, ale nie mogła wesprzeć pamięci inaczej niż „tylko" byciem. Jak każdy przedmiot w teatrze Dormana, szafa miała „swoją biologię" wkraczała z własną pamięcią, ostentacyjną obecnością, zyskując wartość zmienioną w stosunku do tej, jaką miała w rzeczywistości pozascenicznej.

W tekście szafa wyznaczała granicę między życiem a śmiercią, organizując czasoprzestrzeń akcji. Na scenie stawała się obiektem wielofunkcyjnym: wydobywała napięcie wynikające $\mathrm{z}$ ciasnoty i niewygody, napędzała akcję, spajała pla-

\footnotetext{
$24 \quad$ J. Dorman, Pisanie reżysera ..., op. cit.

25 Ibidem.

26 K. Grębski, op. cit., s. 30.

27 J. Dorman, notatka bez daty, między 7 a 9 IV 1985 (prawdopodobnie 8 IV), rkps, sklejka „Powiedz, że jestem...”, op. cit.

28 Ibidem. Scena obrotowa została zastosowana w scenografii przedstawienia Która godzina, w każdej z trzech realizacji.

29 Została zakupiona „z kiesz[eni] Teatru”, J. Dorman, notatka, 12 IV 1985, ibidem. Zob. też wywiad z J. Jackowiczem, op. cit.

30 J. Dorman, „Przedmioty”, notatka bez daty, mps, AJD/IT.
} 


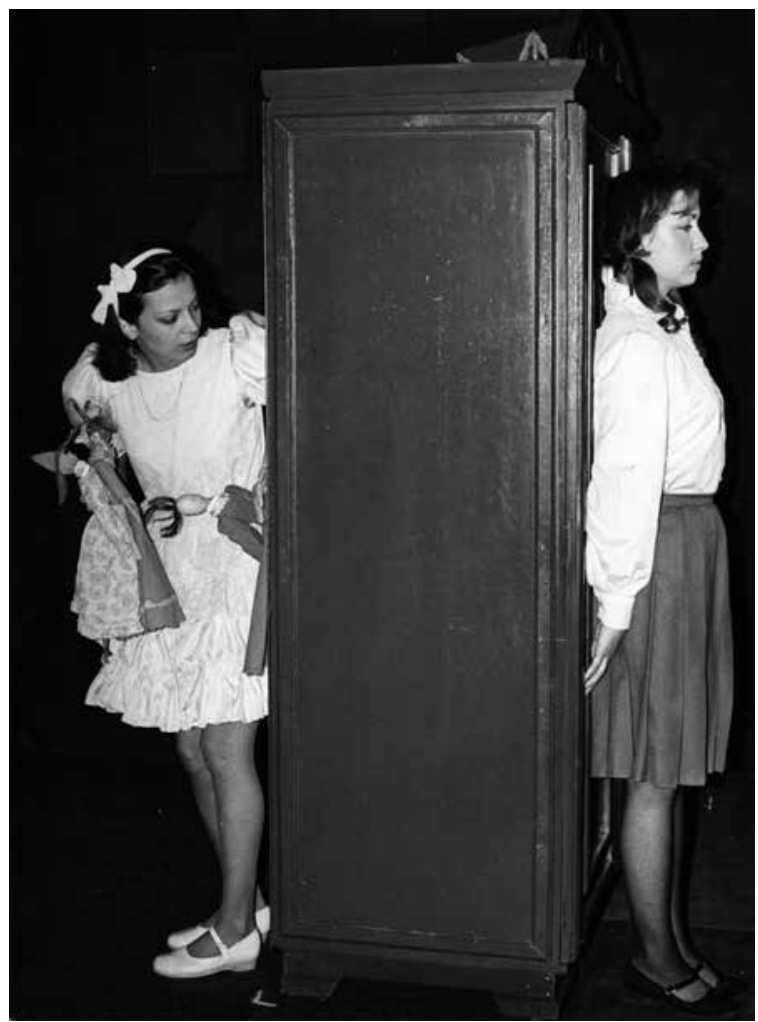

Powiedz, że jestem... Hanny Krall, Teatr Dramatyczny im. J. Szaniawskiego w Wałbrzychu, 1985, Archiwum Jana Dormana w Instytucie Teatralnym

ny czasowe umożliwiając ich przenikanie się, przypominała, chroniła, zabraniała, katalizowała „ruch” wspomnień i emocji, użyczała swojego wnętrza, wydawała dźwięki, była przemieszczana. Grała swoją partię bezwładnie, ale intensywnie obecna, obdarzana traumatyczną uwagą lub czułością. Bohaterowie koncentrowali się wokół niej, dotykając i ogrywając ją. Dorman czytał sztukę Krall z perspektywy szafy, wierny swej strategii: ,układ (partytury) rozpoczynam od wprowadzenia na scenę rekwizytu, który w inscenizacji jest przedmiotem działania". ${ }^{31}$ Dynamiczne, wykonane kilkoma kreskami rysunki ukazują fascynację reżysera sensualnym, dominującym rekwizytem, obdarzonym obiektywną tożsamością (wiadomo z przebiegu przedstawienia, kto wykonał mebel, znana jest jego cecha szczególna, rozsuwana tylna ściana).

Ta szafa nigdy już nie miała być anonimowa w przeciwieństwie do wielu innych rzeczy ocalałych z Zagłady. Obrazy zagrabionego żydowskiego mienia widział każdy, kto odwiedził teren obozu koncentracyjnego. Zgrzebność i utylitarność

$31 \quad$ Idem, Moje credo..., op. cit., s. 43. 
nagromadzonych przedmiotów przypominają, że wywożeni zabierali ze sobą najpotrzebniejsze i/lub najbardziej wartościowe rzeczy, stąd gabloty pełne okularów, protez, portfeli itd., swą masowością wskazujących na skalę Zagłady. Szafa zestawiona z pożydowskimi drobiazgami jest szokująco przeskalowana. ${ }^{32} \mathrm{Krall}$, upominając się o obecność konkretnego obiektu, otwiera nową perspektywę powojennego dialogu. Różnica skali pozwala dostrzec jednostkowe doświadczenie i jednocześnie kieruje narrację i recepcję ku rejonom, w których przetrwało życie.

Nie tylko szafa stanowiła istotny rekwizyt kierunkujący sceniczną opowieść. Również drobniejsze przedmioty, wiążąc ze sobą plany czasowe spektaklu, stanowiły swoiście rozumiane media pamięci. Wieniec pogrzebowy, wnoszony w scenicznej teraźniejszości, był wyrzucany w obrazie z przeszłości. Biała rękawiczka, niedbale rzucona na podłogę w planie współczesnym, przykuwała uwagę widzów do momentu, w którym - w planie przeszłym - jedna z postaci podnosiła ją i w znaczący sposób ogrywała. Delikatnie zaznaczona na samym początku (teraźniejszość) kwestia biżuterii miała powrócić jako istotny motyw pod koniec przedstawienia (przeszłość). „Szafa, lalki, rękawiczka, czako [...] grały [...] na równi z aktorami" ${ }^{33}$ - spajając czasy akcji. Zwielokrotnienie nadrzędnej struktury spektaklu montowało jego wewnętrzną logikę, być może wywiedzioną przez Dormana z uwagi dramatopisarki o obsadzie poszczególnych ról. I choć bez wątpienia „najgłówniejszym elementem scenograficznym jest szafa" ${ }^{4}$, to mikronarracje, przypisane drobniejszym rekwizytom, zagęszczały opowieść, działając na podobnej zasadzie co współczesny hipertekst: odsyłały dalej, pozwalały zagłębić się w meandry historii - lub zbagatelizować, bo nie każdy link w danym tekście jest dla czytelników równie interesujący.

Spoiwem funkcjonującym w podobny sposób co przedmioty, była muzyka Rafała Augustyna stworzona na motywach I symfonii D-dur Tytan Gustava Mahlera oraz wykorzystane fragmenty samej symfonii. Warstwa muzyczna, podniosła, niekiedy patetyczna, miała uwypuklić kluczowe momenty przedstawienia i wzbogacać jego fakturę. Mahlerowskie motywy przenikały zarówno plan współczesny, jak przeszły, dodatkowo podkreślając ich spójność i relację. Nie bez znaczenia było również żydowskie pochodzenie Mahlera, o którym Dorman doskonale wiedział.

\section{Kształt sceniczny}

Aby wśród napięć i emocji słowa zabrzmiały w pełni, musiała im towarzyszyć forma teatralna. Istotną rolę odgrywało światło wydobywające np. kluczowe kwestie Pani Stachowej35 lub punktujące rekwizyty. Ważna była również ekspresja aktorska: analiza zachowanych fotografii sugeruje, że rozwijającym fabułę scenom

\footnotetext{
32 Zob. B. Shallcross, Rzeczy i Zagłada, Kraków 2010, zwłaszcza s. 7-25.

33 K. Grębski, op. cit., s. 33.

34 J. Dorman, Szafa, [w:] Powiedz, że jestem... [program], op. cit.

35 Wywiad z Krzysztofem Grębskim przeprowadzony przez Monikę Tomczyk, 11 IV 2017, nagranie dźwiękowe, AJD/ IT.
} 
dialogowym towarzyszyły drobne gesty, bliskie codziennym działaniom „zachowane zachowania”. Dopiero symboliczna, budząca emocje scena zabawy Dziewczynek czy pełna napięcia wymiana zdań między Matką Dziewczynki II a Mężczyzną wyzwalały szerszy gest: wyprostowaną rękę, gwałtowny ruch, naprężone ciało. Słowa stanowiły stelaż do rozpięcia struktury afektywnej, na tej strukturze dopiero budowane były dynamika ciał, ruch w przestrzeni i ekspresja nastrojów. Kluczowe okazywały się niemożliwe do wyartykułowania stany psychofizyczne, nieuspokojone emocje w ciałach i wspomnieniach, wyparte doświadczenie, które nieoczekiwanie się ujawniało. Dorman powściągliwie uruchamiał pełną tajemnic narracyjną machinę emocji, ograniczając ją do sygnałów. Sugerując widzowi samodzielną pracę z przedstawieniem, nie zakładał konkretnego punktu dojścia.

\section{Montaż sceniczny}

Wierny tekstowi Dorman zastosował w spektaklu skokowy montaż scen. Obrazy z teraźniejszości i z przeszłości wzajemnie się komentowały i uzupełniały, wyjaśnienia te jednak nie były widzom podawane wprost, wynikały raczej z teatralnej konstrukcji. Reżyser wymagał od widzów aktywnej uwagi i czujności na pozornie nieistotne fragmenty dialogu czy rekwizyty. Przejścia między kolejnymi obrazami były efektem magicznego zaklinania (w warstwie tekstowej) bądź wyczerpania się tematu danej sceny. Bo też tematy a nie chronologia dyktowały reżyserowi momenty cięć:

podobnie, jak to dzieje się w filmie, na stole montażowym. [...] Temat nie zawsze rozwija się [...] według chronologicznych następstw, a jest raczej sumą obrazów zbudowanych na zasadzie skojarzeń (podobieństwo, przeciwieństwo). ${ }^{36}$

\section{PRZEDSTAWIENIE}

Inscenizację rozpoczynał fragment I symfonii Mahlera, znany również jako Marsz pogrzebowy. ${ }^{37}$ Pani I i Córka Pani I przychodzą z wizytą do umierającej Pani II. Wejście kobiet jest zrytmizowane, nierealistyczne, przychodzą z wnętrza szafy; być może są wspomnieniami lub marzeniami Pani II w ostatnich chwilach jej życia albo i po jej śmierci („,czy te panie nie przyszły już na cmentarz” ${ }^{38}$, pyta retorycznie w didaskaliach scenariusza reżyser). Kobiety przynoszą kwiaty, jednak nie konwencjonalny bukiet, ale wieniec pogrzebowy, dodatkowo wydobywany światłem ${ }^{39}$, składają go na pianinie jak na katafalku.

36 H. Ćmok, Ja - Henryk Ćmok - o Dormanie!, [w:] Niebieski ptak [program], Będzin 1963, AJD/IT.

37 Zob. K. Grębski, op. cit., aneks, s. 1.

38 J. Dorman, notatka, 11 IV 1985, rkps, sklejka „Powiedz, że jestem...”, op. cit.

39 Dorman poświęca kwestii oświetlenia wieńca wiele uwagi, rozrysowuje je w przestrzeni sceny i podkreśla konieczność ekspozycji, zob. J. Dorman, notatka, 12 III 1985, rkps, sklejka „Powiedz, że jestem...", op. cit. 


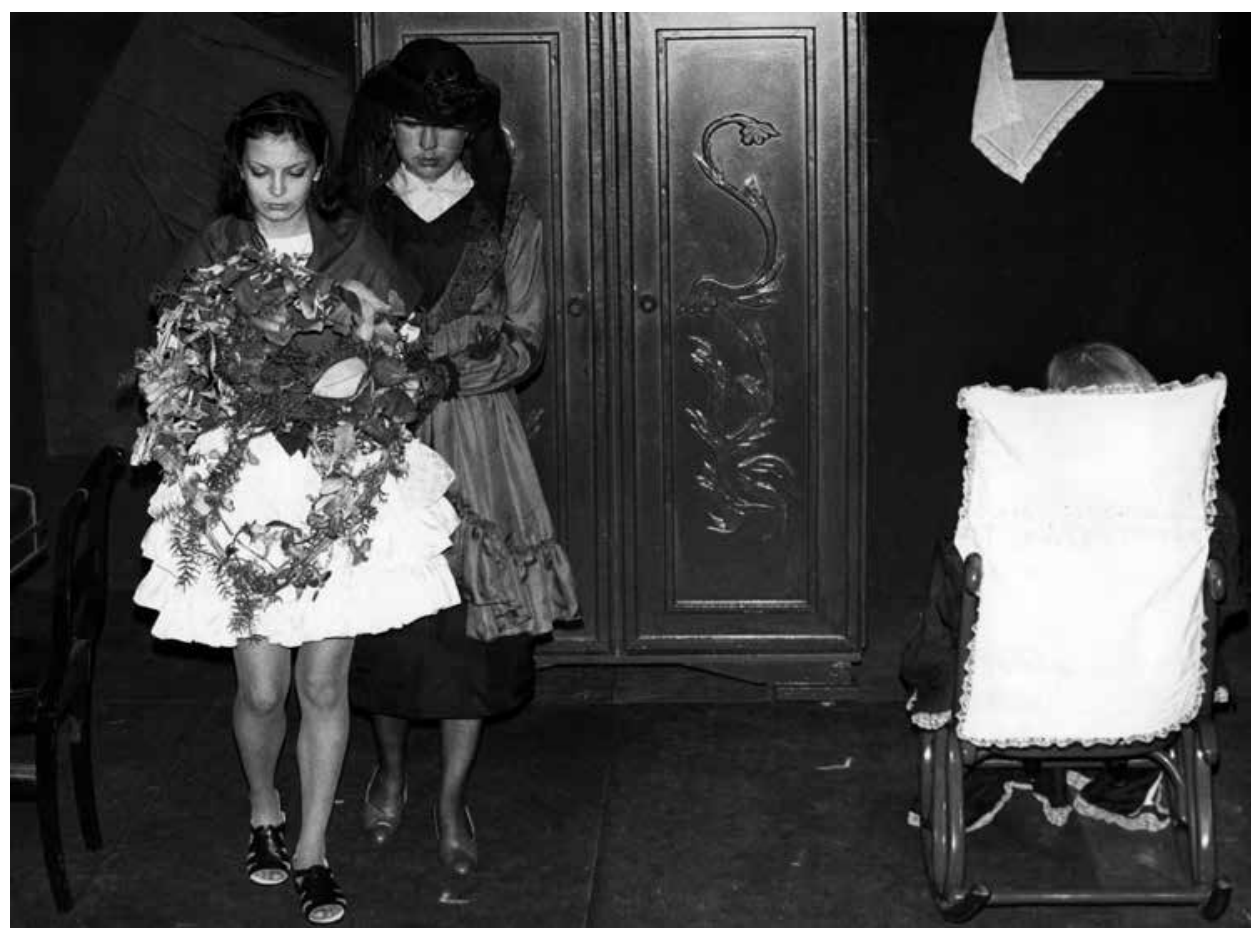

Powiedz, że jestem... Hanny Krall, Teatr Dramatyczny im. J. Szaniawskiego w Wałbrzychu, 1985, AJD/IT

Pani II siedzi w zwróconym tyłem do publiczności bujanym fotelu już podczas wejścia widzów. „Ożywa” dopiero, gdy do jej mieszkania wchodzą goście. ${ }^{40}$ Kobieta pragnie ofiarować Córce Pani I złoty łańcuszek, ta jednak odmawia jego przyjęcia. Biżuteria powróci jeszcze w spektaklu.

Pani I „wchodzi do szafy sanktuarium”41, nie może z niej wyjść „i to w żadną stronę". ${ }^{42}$ Z szafy dobiega łomotanie, potężnieje muzyka marszowa. ${ }^{43}$ Wydarzenie uwypukla ontologiczną niepewność sytuacji i rozdarcie między historią a teraźniejszością, ogniskuje uwagę widza na szafie, kluczowym rekwizycie, który uruchamia plan historyczny i antycypuje przyszłe perypetie. Dziwną sytuację przerywa wejście Chłopca, w którym Pani I dostrzega podobieństwo do jego ojca. Naprowadza ją na ten trop głos Chłopca (o tym, dlaczego głos, a nie wygląd, publiczność niebawem się dowie). Jego ojciec jednak zmarł, a młody człowiek

40 „Pani II już dawno siedzi + właściwie nie może się ruszać, bo nie jest jeszcze «ożywiona»”; „z szafy wychodzi Pani I i córka”, J. Dorman, notatka 18 IV 1985, rkps, ibidem.

41 J. Dorman, notatka, 23 V 1985, rkps, ibidem.

42 Ibidem.

43 K. Grębski, op. cit., s. 30. 
trzykrotnie powtarza „nie pamiętam pogrzebu mojego ojca”. ${ }^{44}$ Zwielokrotniona fraza, echo Dormanowskich gier z rytmem, to zaklęcie uruchamiające przeszłość. Chłopiec odwraca Panią II przodem do publiczności - twarz kobiety przysłania woal upodabniający ją do twarzy stojących na scenie manekinów. Chłopiec znika pomiędzy manekinami, gaśnie światło. Wkracza przeszłość.

Narrację historyczną otwierał obraz skulonej za szafą Dziewczynki I ze szmacianymi lalkami w ręku, kiwającej się na podobieństwo dzieci dotkniętych chorobą sierocą, opowiadającej samej sobie historię Jasia i Małgosi. Lalki, pozbawione oczu, włosów, niedoskonałe, „są jedynymi powiernikami samotności zagrożonego dziecka" ${ }^{45}$, "gromochronem dziecięcych klęsk". ${ }^{46}$ Dziewczynka nie tylko rozmawia z nimi i bawi się, ale może za ich pośrednictwem również się modli. Trudno powiedzieć. W świecie, z którego wyrugowano Boga, zwrot ku antropomorficznym rzeczom może być jedynym ratunkiem zagubionego człowieka.

Toczy się performatywne działanie Dziewczynki I. Szafa staje się piernikową chatką. Do zabawy dołącza Dziewczynka II, wchodząc w rolę Baby Jagi, multiplikując zdania i wypowiedzi (,dobry Bóg dopomoże”, „chrupki chrupki chrupki” itd.). Cała scena w wyobraźni reżysera stanowiła ruchowo-słowną całość. Dorman rozrysował jej kolejne etapy w sposób przypominający filmowy storyboard. ${ }^{47}$ Dziewczynki nie dostrzegają okrutnej niestosowności zabawy zakończonej wrzuceniem Dziewczynki II/Baby Jagi do szafy, która na tę chwilę staje się piecem. Sytuację przerywa Matka Dziewczynki II; jej interwencja i pełne niepokoju kwestie uświadamiają widzom realną stawkę tej „,gry”.

Do scenicznego mieszkania przybywa Pani Stachowa, żona Stacha, konstruktora szafy. Jej wejście (Dorman nazywa je ,intermedium”"48) wprowadza surową rzeczywistość: kobieta zadaje pytania o rodziców Dziewczynki I, naruszając domyślną strategię nierozmawiania o nich. $\mathrm{O}$ wojnie mówi bez peryfrazy czy metafory. Reżyser utożsamił Panią Stachową z „wędrującą” po jego przedstawieniach Matką Courage, wielką postacią ze sztuki Bertolta Brechta. Przyporządkował jej ikoniczny dla jego wizji Matki Courage gest bicia w bęben, tak nieoczekiwany wobec dotychczasowej materii przedstawienia. Postać wnosiła coś szczególnego, „czego się w życiu nie spotyka"49, nową energię wynikającą ze zmiany rytmu i rozpoczęcia nowego tematu. W opozycji do zawartych w jej kwestiach realistycznych treści, forma teatralna jest z innego, specyficznie Dormanowskiego porządku: marszowy krok, okrążanie sceny, rytm wybijany na przytroczonym do ciała bębenku, rytmiczne frazy tekstu - wszystko to nasuwało militarne skojarzenia

44 J. Dorman, notatka, 23 V 1985, sklejka „Powiedz, że jestem...”, op. cit.

45 K. Grębski, op. cit., s. 33.

46 J. Dorman, „Impulsywne zabawy dzieci”, mps, AJD/ IT.

47 Idem, rysunki z prób lub do prób, 23 V 1985, rkps, sklejka „Powiedz, że jestem...”, op. cit.

48 Ibidem.

49 Idem, „Szczęśliwy ksiązę, inscenizacja oparta na utworach Oscara Wilde, opracowanie Jan Dorman, Będzin, rok 1967”, sklejka „Szczęśliwy książę”, s. 7, AJD/IT. 
(jednak postać „do widowni mówi potoczną intonacją, ${ }^{50}$ ). Bohaterka łączyła komizm formalny z grozą wojny, wnosiła na scenę pamięć minionych przedstawień, łamiąc realizm pozwalała sobie na bezwstyd jawnego mówienia o wojnie. ${ }^{51}$ Zabiegi formalne pozwalały jej wypowiedzieć słowa nie do powiedzenia w scenicznym realizmie: o wózkach wiozących ciała zmarłych (w domyśle: Żydów), o mężu, fachowcu, który może zbudować nawet trumnę. Orientując się, że słowo „trumna” wypowiedziane w obecności Dziewczynki I jest niestosowne, próbuje je wymazać, powtarzając trzykrotnie ,nie mówię przecież, że będzie potrzebna”. ${ }^{52}$ Kwestię tę „mówi jak litanię [...] jak pacierz". ${ }^{33}$ Groteskowa, ocierająca się o rubaszność bohaterka odsłania w ten sposób autentyczną emocję przez czysto formalny zabieg teatralny.

Między wyjściem Pani Stachowej a powrotem do narracji teraźniejszej umieszczona została dopisana przez Dormana niema scena żydowskich zaślubin. Odbywała się w ramie stworzonej przez otwartą z przodu i z tyłu szafę. Przywołuje to drugoplanowy wątek zaślubin Dziewczynki II/Pani II i Chłopca, ale też jeszcze mocniej nasyca mebel symboliką: za pośrednictwem szafy można wkroczyć w dorosłość, jest ona przestrzenią liminalną.

Dwa kolejne obrazy to interesująca konstrukcyjnie strategia uscenicznienia takiej pamięci, która, choć niechciana, towarzyszy człowiekowi przez lata. Córka Pani I usiłuje zrozumieć niegdysiejszą konieczność ukrywania się jej matki. Dialog rysuje przepaść między wypartą, przymusowo nieobecną historią traumy starszego pokolenia a otwartością nieświadomej młodzieży. Pani I próbuje zbudować pomost nad tym rozziewem, opowiadając o polowaniu na Żydów przy pomocy metafor, porównując wojnę do treści filmu. To jednak nie działa, a na nic więcej Pani I nie potrafi się zdobyć. Dorman natychmiast uświadamia widzom, skąd bierze się ta niemoc: w kolejnym obrazie (przeszłość) Dziewczynka I zakłada na głowę opaskę z gwiazdą Dawida jak koronę. Żydowska „księżniczka” z udziałem lalek odgrywa niemą scenę powitania i po chwili również pożegnania samej siebie. Tylko tak, przez symbol lub metaforę, może mimo sytuacji ukrycia wyrazić samą siebie.

Dialog z lalkami przerwany zostaje przez dzwonek u drzwi. Dziewczynka II upewnia się, czy ktokolwiek mógł usłyszeć jej żydowską przyjaciółkę, czy grała na pianinie (nawet ekspresja twórcza została odebrana ukrywającej się nastolatce). Dziewczynka I chowa się do szafy. Spomiędzy manekinów wchodzi Chłopiec (późniejszy mąż Pani II), z którym Dziewczynka II wspólnie uczy się matematyki (na poziomie symbolicznym jest to znaczące szukanie wspólnego mianownika, jak próba ułożenia świata w koherentną całość). Chłopiec nie może dowiedzieć się o istnieniu Dziewczynki I. Ta, schowana w szafie, jedynie go słyszy i na tej podstawie wyobraża go sobie (to wyjaśnia wcześniejszy wątek syna Pani II i jego głosu).

\footnotetext{
50 Idem, rysunki z prób lub do prób, 23 V 1985, rkps, sklejka „Powiedz, że jestem...”, op. cit.

51 Ibidem, opisy, rysunki i szczegółowa, kilkustronicowa choreografia wejścia tej bohaterki.

52 H. Krall, op. cit., s. 12.

53 J. Dorman, notatka, 23 V 1985, rkps, sklejka „Powiedz, że jestem...”, op. cit.
} 


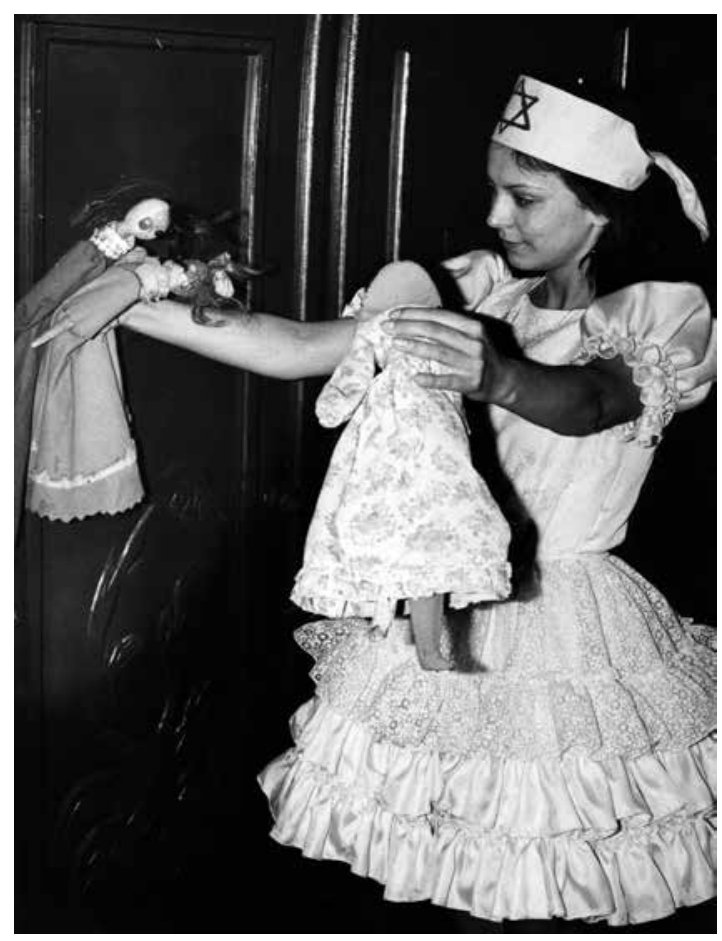

Powiedz, że jestem... Hanny Krall, Teatr Dramatyczny im. J. Szaniawskiego w Wałbrzychu, 1985, $\mathrm{AJD} / \mathrm{IT}$

Dziewczynka II i Chłopiec półsłówkami sygnalizują sobie skrywane tajemnice. Jednak sekretu Chłopca Dorman postanowił nie ujawniać, zostawiając widzowi przestrzeń do samodzielnej interpretacji. Po wyjściu gościa następuje pełna napięcia wymiana zdań między Dziewczynkami o niesprawiedliwej różnicy między nimi: „tylko" kolor oczu decyduje o tym, jaki los przypadł każdej z nich. W kulminacyjnym momencie dialog zostaje przerwany kolejnym dzwonkiem do drzwi - to jeszcze jeden gość, nowy, choć w planie symbolicznym pojawił się wcześniej.

W tekście Krall dopiero w tym momencie na scenę wchodził Mężczyzna (szmalcownik). Reżyser zdecydował: „Będzie inaczej. Wejście aktora zostanie zwielokrotnione" 54 - postać pojawiała się pomiędzy scenami, na kształt synkopowego zakłócenia, wizualnego refrenu. W kolejnych niespiesznych, niemych wejściach Mężczyzna spoglądał na stojące na szafie czako, przesuwał je, by było lepiej widoczne, w końcu zdejmował z szafy, by w czwartym wejściu, już w scenie dialogowej, wnieść je pod pachą. Za każdym razem wkraczał od strony publiczności, a gdy wstępował na scenę, jego kroki ulegały zakłóceniu, jakby zmie-

54 Idem, Czapa, [w:] Powiedz, że jestem... [program], op. cit. 
niała się gęstość powietrza. Jednoznacznie zarysowana w tekście postać została zabiegami reżyserskimi odrealniona. Jego milczące wejścia, zatrzymujące akcję na kształt efektu stopklatki ${ }^{55}$, przygotowywały publiczność na scenę dialogową.

Pomysł na funkcjonowanie anachronicznej czapy narodził się przed próbami: „nakrycie głowy [Mężczyzny] musi być kotylionowe. Będzie nosił na głowie czako ułańskie - czako myli, to tylko ubiór” ${ }^{56}$, a Mężczyzna poprzez czako „zdradza swoją zdradę”. ${ }^{57}$ Zamysł reżyserski uszczegółowił Krzysztof Grębski: „,[Mężczyzna] aby zatuszować swą podłość manifestował swoje rzekome przywiązanie do reliktów tradycji narodowej" ${ }^{58}$ Dorman wprowadził odwołanie spinające plany czasowe spektaklu z odleglejszą historią, za pomocą której Mężczyzna próbował zamaskować małostkowość swego czynu. Pomysł ten mógł być dla widzów trudny do odczytania, budował jednak atmosferę dystansu wobec postaci.

Wejście Mężczyzny wzbogacało przedstawienie o kolejne łączenia planu teraźniejszego z historycznym przy pomocy znaczącego rekwizytu. W pierwszym obrazie (teraźniejszość) na podłogę sceny rzucana była biała rękawiczka, drażniąca oko widza wśród scenicznych czerni i szarości. Pozostawała tam przez kolejne sceny. Z początku wydawać się mogła jednorazowym niedopatrzeniem wykonawców, jednak im dłużej leżała na scenie, tym bardziej publiczność utwierdzała się w przekonaniu o jej istotnej roli. ${ }^{59}$ Dopiero Mężczyzna podnosił ją, ,jakby to był dowód jakiejś nieprawdopodobnej zbrodni” ${ }^{60}$, i posługując się tylko dłonią w rękawiczce, dokonywał inspekcji mieszkania. Aryjczyk, z blond lokami i nieruchomą, pozbawioną mimiki twarzą ${ }^{61}$, wiedział lub domyślał się, że Matka Dziewczynki II kogoś ukrywa. Prowadząc z kobietą dialog oparty na niedopowiedzeniach, dotykając szafy, uderzając w nią pięścią, badając pianino, lustrował mieszkanie w poszukiwaniu śladów obecności „obcych” i sugerował, że nerwowość Dziewczynki II i jej Matki musi mieć jakieś podstawy. Sceniczna obecność Mężczyzny oparta została na gwałcicielskim naznaczaniu rekwizytów i scenografii: dotykał stojących przy pianinie krzeseł, ciskał wieńcem pogrzebowym (tym z pierwszej sceny), przesuwał dłonią po szafie, w końcu odnajdywał schowaną pod klapą pianina opaskę z gwiazdą Dawida. Odkrywając sekret, Mężczyzna znów przez dwuznaczne sformułowanie („To pani tu jakieś skarby przechowuje... I nie podzieli się pani nimi z porządnym człowiekiem" ${ }^{62}$ ) wymuszał na Matce Dziewczynki II haracz. Jego milczenie kobieta kupiła pamiątkowym pierścionkiem, który szmalcownik schował do wnętrza rękawiczki.

\footnotetext{
55 K. Grębski, op. cit., s. 31.

56 J. Dorman, notatka bez daty [9 IV 1985?], rkps, sklejka „Powiedz, że jestem...”, op. cit.

57 Idem, Czapa, op. cit.

58 K. Grębski, op. cit., s. 32.

59 Wywiad z Krzysztofem Grębskim, op. cit..

60 K. Grębski, op. cit., s. 32.

61 Wywiad z Jackiem Jackowiczem, op. cit.

62 H. Krall, op. cit., s. 24.
} 
Napięcie zbudowane w tej scenie znajdowało kulminację w momencie, w którym Mężczyzna trzaskał klapą pianina, co mogło brzmieć jak wystrzał. ${ }^{63}$ I dopiero wejście Pani Stachowej, po którą posłała Dziewczynkę II jej matka, napełniało intruza niejasnym strachem: Stachowa odbierała mu czako, szmalcownik w popłochu uciekał, by definitywnie zniknąć ze sceny. Interakcja ta podkreślała wagę bohaterki: nieśmiertelna, potężna Matka Courage ma moc ocalającą, przywraca godność i należne miejsce wydarzeniom historycznym. Realność wojny, którą ze sobą wnosi, jest przerażająca nawet dla szmalcownika.

Przestraszona najściem Mężczyzny Dziewczynka I postanawiała opuścić mieszkanie. Pani Stachowa zwięźle zapowiadała: „pójdzie ze mną”. ${ }^{64}$ Pomagając Dziewczynce I ubrać się, Matka Dziewczynki II wręczała Pani Stachowej złoty łańcuszek (ten sam, który w pierwszej scenie Pani II chciała podarować Córce Pani $\mathrm{I}^{65}$ ), na wypadek gdyby trzeba było opłacić milczenie kolejnej osoby. Dziewczynki żegnały się ze sobą, a przypomniawszy sobie Chłopca, Dziewczynka I prosiła przyjaciółkę: „A jak on przyjdzie... [...] Powiedz mu o mnie. Powiedz tylko, że jestem". ${ }^{66}$

Sytuacja teatralna odsłoniła przestrzeń złożonych stanów psychicznych, traumy zmieszanej z wdzięcznością, ocalenia połączonego z zachwianiem tożsamości. Cicha odwaga Matki Dziewczynki II oraz Pani Stachowej ocaliły Dziewczynkę I, czy jednak ratunek nie stał się przekleństwem? Czy Dziewczynka I, udająca, że jej nie ma, nie doznała zachwiania swego istnienia? Tytułowa fraza to przecież prośba o przekazanie śladu obecności, ale również próba samopotwierdzenia własnego istnienia w drugim człowieku.

Na cichej prośbie „Powiedz, że jestem” kończył się (a raczej urywał) dramat Krall. Dorman dopisał do niego inscenizacyjny finał. Spomiędzy manekinów wysuwała się dłoń Chłopca z nieszczęsną opaską z gwiazdą Dawida. Dziewczynka I, biorąc opaskę, dawała się wyprowadzić Pani Stachowej. Na scenie zostawały Dziewczynka II i jej matka. Niememu obrazowi towarzyszyła muzyka, w trakcie której przez około minutę przygasało światło. W ciemnościach przez kolejną minutę (czyli bardzo długo miarą czasu scenicznego) rozlegała się muzyka. Takim obrazem, celowo rozciągniętym, reżyser kończył przedstawienie. Mocny, wzruszający przekaz emocjonalny mógł zostać podczas wydłużonego finału szybko, „roboczo” przepracowany przez widzów; „oni się wstydzą [...] i muszą mieć czas, żeby odreagować", tak ten zabieg tłumaczył Grębskiemu Dorman. ${ }^{67}$

63 „Czy uderzenia «klapą» pianina, to tylko trzask” - pytał w programie reżyser; J. Dorman, XXX, [w:] Powiedz, że jestem... [program], op. cit.

64 H. Krall, op. cit., s. 26.

65 W wersji tekstu Krall, z którym pracował reżyser, Matka Dziewczynki II wręczała Pani Stachowej broszkę, z czego Dorman zrezygnował. Por.: H. Krall, op. cit., s. 27; K. Grębski, op. cit., s. 60.

66 H. Krall, op. cit., s. 26.

67 Wywiad z Krzysztofem Grębskim, op. cit. 


\section{OD STRONY WIDZA}

\section{Recepcja}

Lektura recenzji pozwala docenić reżyserską rezygnację z retoryki bohaterstwa i nomenklatury wiktymizacyjnej. Ufając pozbawionemu ozdobników językowi Krall, Dorman zetknął na scenie Historię i historię, tożsamość i pamięć, życie i Zagładę, splatając z nich skomplikowany i gorący węzeł emocjonalny. Prostota przedstawienia wyzierająca $\mathrm{z}$ fotografii podkreślała, że w spektaklu nie było miejsca na narrację bohaterską, automatyzm empatii czy źle pojętą wzniosłość. Istotne było jednostkowe życie, modelowa wersja jednej z dróg prze-życia Zagłady. Dostrzegła to krytyka - recenzje (nieliczne) z akceptacją wspominają o „wadze przedstawienia"68 i skupieniu widowni podczas spektaklu, trafnie odczytują inscenizacyjne zależności i sensy.

Temat obecności szafy na scenie podnosi Krzysztof Kucharski. ${ }^{69}$ Budując w swojej recenzji napięcie i suspens, przywołał motyw szafy w ówczesnych dolnośląskich przedstawieniach, akcentując, że ta wałbrzyska ma znaczenie szczególne. Podkreślił migotliwość znaczeń mebla, odczytał wielopoziomowe komunikaty przezeń wysyłane. Zaznaczył, że „Dorman przywiązywał [...] dużą wagę do przedmiotów. Dawał im życie, czynił je bohaterami, podnosił do rangi symbolu, alegorii”. Po takiej, z konieczności skrótowej charakterystyce twórczości dodawał, że w Powiedz, że jestem... znaleźć można realizację tej praktyki.

Również Wanda Jesionowska i Irena Keller, piszące w „Teatrze” o wałbrzyskim festiwalu, nazwały szafę „symbolem” i opisywały jej wielorakie funkcjonowanie sceniczne. ${ }^{70}$ Doceniając tematykę i oryginalność jej ujęcia, dostrzegały zarazem kłopot z odbiorem przedstawienia. Zauważały, że symbolika ,nie zawsze staje się w pełni czytelna dla małego widza" "71 przywołując w charakterze przykładów wątek czako i rysy Matki Courage w postaci Pani Stachowej. W opinii recenzentek były to elementy domagające się świadomej i przygotowanej publiczności. Mimo to podkreślały, że przedstawienie skupiało uwagę, a w repertuarze festiwalu było atrakcyjne i świeże.

Doceniła inscenizację również autorka sztuki, bezpośrednio wyrażając to w korespondencji z reżyserem. W liście, poświęconym planom prezentacji wałbrzyskiego spektaklu w Tel Awiwie bądź realizacji izraelskiej premiery, Krall napisała: „Cieszę się, że nie stracił Pan czasu, robiąc to moje sztuczydełko [...]. Na wszelki wypadek nie zgodzę się na żadnego innego reżysera - nigdzie". ${ }^{72}$

68 W. Jesionowska, I. Kellner, Po IV Watbrzyskim Festiwalu Sztuk Dziecięcych, „Teatr” nr 1985 nr 10.

69 K. Kucharski, op. cit.

70 W. Jesionowska, I. Kellner, op. cit.

71 Ibidem.

72 List H. Krall do J. Dormana, Warszawa, 8 VIII 1985, rkps, sklejka „Powiedz, że jestem...”, op. cit. Do realizacji planów wyjazdowych nie doszło. 
Co warte zaznaczenia, nauczyciele docenili przedstawienie, podkreślali, że podejmuje problematykę rzadko obecną w ówczesnych produkcjach dla młodzieży. ${ }^{73}$ Takie głosy oznaczają trafne odczytanie przez dramatopisarkę i reżysera generacyjnych potrzeb poznawczych i celną na nie odpowiedź.

Opinie te pozwalają stwierdzić, że zamysł Dormana, mimo potknięć, sprawdził się w odbiorze. Stało się tak m.in. dzięki temu, że spektakl oddziaływał poprzez „empatyczne wytrącenie z równowagi" ${ }^{74}$, nie stosował strategii szoku, nie łamał tabu. Wsłuchany w potrzeby odbiorców artysta potrafił rozmawiać ze swoją widownią o sprawach ważnych w delikatny sposób.

\section{Statystyka}

Wałbrzyskie przedstawienie pokazano dla 8598 widzów 53 razy w ciągu dwóch sezonów (1984/85: 5 przedstawień, 188 widzów, 1985/86: 48 przedstawień, 8390 widzów).$^{75} \mathrm{~W}$ premierowej obsadzie spektakl zagrany został pięciokrotnie, a od sezonu 1985/86 rolę Córki i Dziewczynki I przejęła Grażyna Madej, Pani Stachowej - Danuta Szumowicz-Łysiak, Mężczyzny - Adam Wolańczyk. ${ }^{76}$

Spektakl otrzymał trzy nagrody podczas festiwalu w Wałbrzychu (doceniono reżyserię, rolę Katarzyny Skolik i pracę całego zespołu aktorskiego). Obok pokazów w siedzibie miał również liczne prezentacje wyjazdowe. Zagrano go w Rogoźnicy (w sezonie 1985/86, pokaz plenerowy na terenie obozu w Gross-Rosen dla około 3500 - 4000 harcerzy), Jeleniej Górze (wrzesień-październik 1985, XV Jeleniogórskie spotkania Teatralne, Panorama Teatrów Ziem Zachodnich z okazji czterdziestolecia ich powrotu do Macierzy), Poznaniu (październik 1985, inauguracja działalności Ogólnopolskiej Sceny Teatralnej dla Dzieci i Młodzieży), Katowicach (styczeń 1986, Teatr Jana Dormana - przegląd przedstawień towarzyszący Spotkaniom Teatrów Wizji i Ruchu), Saint-Malo we Francji (marzec 1986, I Międzynarodowe Spotkania Twórczości Artystycznej dla Dzieci Arts Moins), Szczecinie (kwiecień 1986, XXI Ogólnopolski Przegląd Teatrów Małych Form) i w Opolu (październik 1985, XII Ogólnopolski Festiwal Teatrów Lalek). ${ }^{77}$

\footnotetext{
73 Zob. wywiad z Jackiem Jackowiczem, op. cit.

74 Określenie za: D. LaCapra, Pisanie historii, pisanie traumy, przekł. A. Rejniak-Majewska [w:] Pamięć Shoah. Kulturowe reprezentacje i praktyki upamiętnienia, red. T. Majewski, A. Zeidler-Janiszewska, M. Wójcik, Łódź 2011, s. 528.

75 „Almanach Sceny Polskiej” 1984/85, s. 106 i 1985/86, s. 129.

76 K. Grębski podaje, że i on występował w wałbrzyskiej wersji, m.in. podczas wyjazdu do Rogoźnicy, oraz że rolę Pani Stachowej przejęła Małgorzata Niewiadomska, zob. wywiad z Krzysztofem Grębskim, op. cit. Tych danych nie potwierdza „Almanach Sceny Polskiej”, jednak ze względu na ewentualną niekompletność dokumentacji teatralnej założyć można, że przynajmniej na początku sezonu 1985/86 Niewiadomska i Grębski grali zastępstwa.

77 Zob. „Almanach Sceny Polskiej” 1985/86, s. 197, 199, 200, 206, 244.
} 


\section{KOLEJNE ŻYCIA SPEKTAKLU}

Zasadniczy temat przedstawienia, różnorakie ujęcia pamięci, nie pozostał bez wpływu na dzieje inscenizacji. Szeroko rozumiana pamięć przedstawienia - pamięć o przedstawieniu - również została „przetransmitowana”, a kształt i założenia Dormanowskiej koncepcji ożyły jeszcze dwukrotnie, w zmienionych okolicznościach.

W lipcu 1985 Dorman wraz z grupą studencką wrocławskich Wydziałów Zamiejscowych Państwowej Wyższej Szkoły Teatralnej im. Ludwika Solskiego w Krakowie wziął udział w interdyscyplinarnych, niemal trzytygodniowych warsztatach w Świdwinie, zorganizowanych przez Ogólnopolski Ośrodek Sztuki dla Dzieci i Młodzieży w Poznaniu. Było to przedsięwzięcie mające na celu konsolidację środowisk twórczych pracujących w obszarze sztuki dla młodego widza, pierwsze tego typu zorganizowane przez poznańską placówkę. W grupie Dormana znaleźli się studenci Wydziału Lalkarskiego: Anna Bajer, Ewa Cypcarz, Mariola Łabno, Małgorzata Niewiadomska, Krzysztof Grębski i Marek Tatko. Obok Dormana warsztaty prowadzili: Andrzej Szymalski, Mieczysław Abramowicz, Waldemar Musiał, zespół Teatru „Wierzbak”. Pracowały również: grupa plastyczna, telewizyjna, teatralno-muzyczna i dziennikarsko-literacka. Warsztaty rozpoczęły się 6 lipca, prezentacje efektów odbyły się 23 i 24 lipca. ${ }^{78}$ Dorman zaproponował swojemu zespołowi aktorskiemu realizację Powiedz, że jestem..., a na potrzeby tego szczególnego „przeniesienia” wystarał się o wypożyczenie scenografii z inscenizacji wałbrzyskiej ${ }^{79}$, która została przetransportowana do Świdwina.

Jak wspomina biorący udział w świdwińskiej realizacji Krzysztof Grębski, reżyser przeniósł przedstawienie $\mathrm{w}$ takiej formie, $\mathrm{w}$ jakiej ją „sprawdził w Wałbrzychu". ${ }^{80}$ Mowa tu nie tylko o fizycznym przewiezieniu scenografii, ale również o rytmice, intonacjach i ruchu scenicznym aktorów, muzyce, układzie przestrzeni, ustawieniu świateł oraz treściach spektaklu. Rozpoczynając pracę ze studentami od razu na scenie a nie, jak to dzieje się zazwyczaj, od prób stolikowych ${ }^{81}$, Dorman odgórnie narzucił formę, egzekwując jej wykonanie przez wielokrotne powtarzanie. Osiągnął w ten sposób efekt zespolenia tekstu z ruchem, a dwutygodniowa praca w takim trybie sprawiła, że studenci przygotowali ,identyczne niemal co do kroku powtórzenie realizacji wałbrzyskiej”" ${ }^{82}$ Wtedy dopiero rozpoczął Dorman pracę nad interpretacją. Jednak, co Grębski spostrzega z zaskoczeniem:

78 K. Grębski, op. cit.

79 Już wiosną Dorman zajął się tą sprawą: „mówię o Świdwinie Stasickiemu i Jackowiczowi”,

J. Dorman, notatka, 2 V 1985, rkps, sklejka „Powiedz, że jestem...”, op. cit.

80 Wywiad z Krzysztofem Grębskim, op. cit.

81 K. Grębski, op. cit., s. 24.

82 Ibidem, s. 25. 
okazało się, że nie trzeba poświęcać specjalnego czasu na takie poszukiwania, bo narzucona przez Dormana koncepcja zrosła się w sposób naturalny z wyobrażeniami aktorów, i w ten sposób powstały pełnokrwiste [...] postaci, jakże jednak różne od swoich wałbrzyskich poprzedników. ${ }^{83}$

Różnica między realizacjami polegała przede wszystkim na decyzjach obsadowych. Np. Ewa Cypcarz o słowiańskiej urodzie grała Dziewczynkę I (w Wałbrzychu odtwarzaną przez ciemnowłosą i ciemnooką Katarzynę Smolik), a Małgorzata Niewiadomska - Panią Stachową (w Wałbrzychu grała ją znacznie starsza Krystyna Krasowska-Stożek). Obsadowa roszada mogła być kolejnym sprawdzeniem pomysłu inscenizacyjnego, próbą zuniwersalizowania przedstawienia; być może Dorman zastanawiał się, czy rezygnacja z mimetyzmu wesprze uogólnioną (jednocześnie pełniejszą) refleksję nad pamięcią w kontekście Zagłady i wartości życia człowieka.

Przedstawienie zostało zaprezentowane 22 lipca na głównej scenie Miejskiego Ośrodka Kultury w Świdwinie i w powszechnym odbiorze stanowiło najciekawszy i najpełniejszy artystycznie owoc warsztatów. ${ }^{84}$ Pokazano je jeszcze 20 października 1985 na XII Ogólnopolskim Festiwalu Teatrów Lalek w Opolu. ${ }^{85}$ Wtedy studenci oraz zespół TDSz zagrali jednego dnia obie wersje inscenizacji w tej samej scenografii. ${ }^{86}$

Drugim i ostatnim ,powrotem” Dormanowskiej inscenizacji był spektakl zrealizowany przez Krzysztofa Grębskiego ze studentami PWST we Wrocławiu w $1996^{87}$, w którym Grębski wykorzystał oryginalne manekiny z wałbrzyskiej produkcji. Pozostałe rekwizyty i elementy scenografii zostały przygotowane na potrzeby przedstawienia, jedynie szafę reżyser kupił na zewnątrz, gdy udało mu się znaleźć odpowiednio stary mebel, podążając w ten sposób za myśleniem Dormana o przedmiocie na scenie. Inscenizacja w dużej mierze powtarzała realizacje wałbrzyską i świdwińską. Została kilkakrotnie zagrana w warunkach szkolnych we Wrocławiu, pokazano ją także w Będzinie podczas uroczystości nadania Teatrowi Dzieci Zagłębia imienia Jana Dormana (marzec 1996). Będziński pokaz zakończył wędrówkę Dormanowskiej koncepcji inscenizacyjnej.

Dramat Hanny Krall nie doczekał się kolejnych inscenizacji na polskich scenach zawodowych. ${ }^{88}$ Być może język teatralny domagał się nowych form

83 Ibidem.

84 Wywiad z Krzysztofem Grębskim, op. cit.

8520 X 1985 odbyły się cztery prezentacje tego tytułu, o 9:00, 11:00, 13:00 i 15:00 na Dużej Scenie Teatru im. Jana Kochanowskiego w Opolu. Zob. afisz festiwalowy, archiwum Opolskiego Teatru Lalki i Aktora im. A. Smolki.

86 Wywiad z Krzysztofem Grębskim, op. cit.

87 Ibidem.

88 Odbyła się jeszcze tylko jedna inscenizacja w reż. Barbary Kieras, w wykonaniu nieprofesjonalnego zespołu Morator, prem. 6 II 2015. Zob. „Magiczny ogród, rocznik Młodzieżowego Domu Kultury nr 1 im. Artystów Rodu Kossaków w Tychach” 2016 nr 27, s. 6-7. 
rozmowy o wojennym doświadczeniu. A może prostota tekstu nie wydawała się potencjalnym twórcom interesująca. Zastosowana przez Dormana forma teatralna $\mathrm{z}$ nieoczywistym łączeniem planów uczyniły $\mathrm{z}$ tekstu istotną teatralną wypowiedź o milczącym bohaterstwie, niedającej się zatrzeć pamięci, wdzięczności i odwadze.

\section{PUENTA Z PRZESZŁOŚCI}

Odnaleźć można jeszcze jedną, być może najbardziej zaskakującą, choć kontekstową kwestię związaną z pamięcią i traktującym o niej przedstawieniem. Powiedz, że jestem... stało się, jeśli spojrzeć przez pryzmat historii teatru w Wałbrzychu, rodzajem dziadów odprawianych nieświadomie przez Dormana.

Od 1946 obecny gmach TDSz był prowadzonym przez aktywistów lokalnej mniejszości żydowskim domem kultury i skupiał znaczącą część żydowskiej elity intelektualnej i artystycznej miasta. Jeszcze w latach czterdziestych rozpoczął tam działalność żydowski Teatr Renesans, jedna z niewielu placówek kulturalnych powojennego Wałbrzycha. ${ }^{89} \mathrm{Na}$ gościnne występy przyjeżdżał Teatr Żydowski z Wrocławia ${ }^{90}$, prezentowali się regionalni twórcy amatorscy. Wałbrzyskie Żydowskie Towarzystwo Kultury i Sztuki odremontowało gmach, który w lata pięćdziesiąte wszedł jako Dom Kultury Lewartowskiego; podjęto też (bezowocne) starania o upaństwowienie Teatru Renesans. Z czasem podział na żydowskich i nieżydowskich odbiorców oraz twórców zaczął się zacierać: w mieście widowiska dla dorosłych pokazywała (oprócz Teatru Renesans i wrocławskiego Teatru Żydowskiego) tylko gościnnie występująca scena jeleniogórska. Żydzi chodzili na polskie przedstawienia przyjezdne, Polacy na miejscowe spektakle żydowskie, a kwestie tożsamościowe okazywały się mniej istotne niż dostęp do kultury.

W złożonej sytuacji społecznej i politycznej połowy lat pięćdziesiątych oraz w obliczu zmniejszania się liczby żydowskich mieszkańców miasta Teatr Renesans padł ofiarą centralnie sterowanych działań o charakterze przemocy. Na początku 1955 Centralny Zarząd Teatrów, Oper i Filharmonii w Warszawie polecił Prezydium Miejskiej Rady Narodowej w Wałbrzychu przeprowadzić remont budynku z przeznaczeniem na działalność teatralną. Dialog urzędniczy odbył się ponad głowami pracowników Teatru Renesans, którzy zostali zmuszeni do opuszczenia budynku. Pospiesznie rozpoczęte prace remontowe przerwano na etapie wyburzania ścian, co skłoniło społeczność żydowską do spekulacji o likwidacji placówki i tym samym żydowskiego życia kulturalnego w Wałbrzychu. Pod koniec

89 Por. K. Kobielec, Szkic o kulturze watbrzyskiej w latach 1945-2015, [w:] Watbrzyskie szkice, red. S. Bielawska, Wałbrzych 2015, s. 319.

90 Teatr rozpoczął pracę 8 XII 1946 premierą Krwawego żartu Szolema Alejchema. Pracowali w nim m.in. Ida Kamińska i Jakub Rotbaum. Grano repertuar przekrojowy, od ambitnej literatury po spektakle rozrywkowe. 
1956 Towarzystwo Społeczno-Kulturalne Żydów w Polsce, dotychczasowy administrator i użytkownik budynku, rzeczywiście zostało pozbawione gmachu oraz mienia teatralnego ${ }^{91}$, a przez kolejne lata budynek nie był użytkowany. Dopiero 23 listopada 1964 premierą Zemsty w reżyserii Bronisława Orlicza zainaugurował działalność Państwowy Teatr Dramatyczny w Wałbrzychu.

Temat Teatru Renesans nie pojawił się podczas pracy Jana Dormana w TDSz ${ }^{92}$ i o ile udało się to ustalić, twórcy przedstawienia nie mieli o nim pojęcia. W szerokiej perspektywie wydaje się on jednak zaskakującym uzupełnieniem powyższych rozważań. Wprowadza taki wymiar komunikacji, którego sam twórca nie był świadom: bolesne doświadczenie społeczności żydowskiej powróciło po latach do gmachu teatralnego, ale w zupełnie innych okolicznościach i na nowych warunkach. Powrót nastąpił dzięki temu samemu medium, które kilka dekad wcześniej zostało stamtąd wypędzone. Zupełnie jakby Teatr Renesans przypominał: ,powiedz, że jestem".

91 Zob. P. Wieczorek, Jak żydowski teatr stat się teatrem polskim. Losy wałbrzyskiego „Renesansu”, „Słowo Żydowskie” 2011 nr 2. Tam też znajduje się pełniejsza historia placówki.

92 Wywiad z Jackiem Jackowiczem, op. cit. 